\title{
Chemical thinning of apple blossoms in organic production
}

\begin{abstract}
An experiment on chemical blossom thinning on apple variety 'Summerred'/ M9 was performed in an experimental plantation in Brdo pri Lukovici. Different chemical thinners were applied on apple's fruitlets in organic production. The experiment was designed in 7 randomized block with 13 treatments: 1 . unthinned trees (as a control), 2. hand thinning in June, 3. $1 \% \mathrm{NaCl}$, 4. 1,5\% NaCl, 5. $1 \% \mathrm{CH}_{3} \mathrm{COOH}, 6.3 \% \mathrm{CH}_{3} \mathrm{COOH}$, 7. $3 \%$ CaSx, $8.1 \%$ rape oil, 9. $3 \%$ rape oil, 10 . 3\% of sunflower oil, $11.3 \%$ soybean oil, $12.5 \%$ dextrin, 13 . emulsifier $100+$ OCA 30. Chemical thinners were applied in a phenological stage at peak blooming with a manual knapsack sprayer. The best thinning of fruitlets (similar to hand thinned trees) was observed with $3 \%$ rape oil, however, relatively strong russeting of fruit skin was detected in this treatment. Statistically significant reduction of final fruit set also occurred when 1,5\% $\mathrm{NaCl}$ and $3 \%$ soybean oil were applied, but withlessfruit russeting.
\end{abstract}

Key words: apple tree/chemicalthinning/organic production

\section{Introduction}

For a stable yield and a quality apple crop, trees with a medium blossom and fruit hanging are needed. For each tree, blooming represents the first stressful situation in the new season as for fruit growers, since it is one of the most important phases in preventing alternative fruit bearing. Since the trees usually bloom too much, the excess flowers need to be removed by mechanical or chemical measures in order to later reduce the need for expensive manual

thinning of small fruits. Thinning is a fruit growing technique with which a balance is established between vegetative and generative growth. There is chemical and mechanical thinning available. However, if pruning is done in reserve, with a larger number of generative buds to ensure fertility depending on climatic conditions, there is a possibility that all buds remain and there is an excess of fruit (it is desirable to have fewer but larger fruits). In this case, thinning is required. Special care is needed when thinning in organic orchards, because a big pallet of synthesized chemicals is forbidden (Dorigoni et al., 2010).

\section{Mechanical thinning of apple blossoms with Darwin}

In recent decades, a machine Darwin (Fruit Tec) has been the most widely used for mechanical thinning of blossom in Europe. This machine is adapted to the cultivation of narrow-spindle apples in dense apple plantations. Coordination between tractor and spindle speeds are important for mechanical thinning to avoid excessive damage to leaves and branches (possible entry points for infections). Plastic wires laid spirally around the spindle strike the blossom evenly over the entire volume of the crowns (Brvar, 2015). The appropriate thinning time from the phenological phases of the balloon phase to the opening of the central flower and the estimated flower must be more than 6 from 10-point scale. The advantage of spindle enfeeblement is the appropriate concept of thinning, with which we significantly reduce the alternating fertility, because we dilute the flowers, but we will not forget the later frost (Gutman-Kobal and Soršak, 2003). 
The best quality of mechanical thinning of the blossom is achieved by using the machine with nylon bands (e.g. Darwin 200 with 216 nylon bands or Darwin 250 with 432 nylon bands) at a driving speed of $6 \mathrm{kmh}^{-1}$ with $180 \mathrm{rpmin}^{-1}$ or $150 \mathrm{rpmin}^{-1}$. At higher speeds than $9 \mathrm{kmh}^{-1}$ higher shaft revolutions per minute are required $\left(210 \mathrm{rpmin}^{-1}\right.$ for a smaller machine and 170 rpmin $^{-1}$ for a larger machine). Higher driving speeds are only recommended in completely flat orchards without ruts (Gutman-Kobal and Soršak, 2003).

Over the last decade, several studies have been conducted on the effects of mechanical thinning in peaches (Reighard and Henderson, 2012), apples (Schupp and Kon, 2014; McClure and Cline, 2015; Mika et al., 2016), pears (Asteggiano et al., 2015) and nectarines (Steyn et al., 2014). The results of mechanical thinning depend largely on the machine configuration and may significantly reduce labour costs (Blanke and Damerow, 2008; Seehuber et al., 2014), but must be provided separately for each variety (Steyn et al., 2014). In practice, mechanical thinning rarely achieves a finite number of fruits, so that chemical thinning or manual thinning of apples is used in addition (Hampson and Bedford, 2011, Kon et al., 2013). The main advantage of mechanical thinning is that it is independent of variety, year or weather conditions (Dorigoni et al., 2010). On the other side, the main disadvantage represents the damage to young leaf shoots in the blooming shoot, which can significantly reduce photosynthesis or in some cases increase the incidence of bacterial fire (Erwinia amylovora Burill) (Greene and Costa, 2012; Ngugi and Schupp, 2009).

\section{Chemical thinning at the time of blooming}

In case of failure of the mechanical thinning, the use of chemical agents permitted in organic fruit growing is required. The chemicals for thinning flowers and fruits are divided into two groups. The first group includes non-hormonal agents, e.g. CaSx (calcium polysulfide), however, there is very little work on chemical thinning in organic production. An experiment in Switzerland compared the effectiveness of NAA (naphthaleneacetic acid), CaSx and BA (benzyladenine) for chemical thinning of apples in organic production. BA and CaSx had an effect on fruit drops similar to NAA, which at that time was an approved chemical for the thinning of apple fruit in conventional farming in Switzerland. CaSx is an approved chemical for the thinning of apples in organic production (Jerala, 2005).

In Norway, from 1990 to 1993 a trial for chemical thinning of apple fruit was carried out with NAA, Ethephon and CaSx in three different varieties. 5\% CaSx was applied in full bloom and showed a mild thinning effect, but in combination with Ethephon this effect increased. This had also a positive effect on the blooming the following year. Alrashedi and Singh (2014) studied the effect of CaSx in combination with olive oil on apples of the varieties 'Cripps Pink' and 'Gala'. Sinatsch et al. (2010) examined the effect of several thinning agents on the variety 'Pinova'. Pfeiffer and Rueß (2002) drew up a list of permissible thinning chemicals for apple blossoms. Lordan et al. (2018) found a good thinning with olive oil in thirteen trials on 'Gala', 'Golden Delicious' and 'Fuji', but the fruit rust content was significantly increased. In contrast, CaSx did not have a consistent thinning effect. The best results for 'Fuji' varieties with more than 500 flowers were achieved by a combination of mechanical thinning with Darwin $(5 \mathrm{~km}$ $\mathrm{h}^{-1}, 320 \mathrm{rpmin}^{-1}$ with 270 wires) and additional chemical treatment. At 'Golden Delicious' 6 $\mathrm{km} \mathrm{h}^{-1}, 230 \mathrm{rpmin}^{-1}$ with 270 wires was the best configuration to achieve the ideal yield in the optimum range.

Depending on the time of thinning according to Wertheim (2000), we distinguish between thinning at the time of blooming and at the time of fruit development. Thinning at the time of blooming is physiologically most ideal for the trees (Davies, 2014). Excess flowers are eliminated and the need for nutrients is reduced, but it can also be risky because it is not yet known 
how fertilization will take place (the carpel is damaged). The principle of blossom thinning includes the mechanisms of burning part of the blossom, which prevents pollination or germination of pollen, e.g. pollen or pollen tube (Fallahi and Willemsen, 2002).

The advantage of thinning out the blossom has got a favorable effect on the differentiation of the flower bud for the next year and a favourable effect on the fruit size. However, at the time of blooming it is not possible to predict exactly how many blossom will be successfully fertilized. Because of spring frost, which can further thin out the blossom and performance, and the lack of fertilization at the time of blooming, growers tend to choose to thin also the fruit. The effectiveness of thinning with growth regulators is influenced by the concentration of the active substance (narrow range of optimal effects), time and method of application (optimal time is only a few hours), leaf mass (application of the whole tree), diversity and various environmental factors. The optimal time of application is determined by the number of days after full blooming or depending on the thickness or diameter of the central fruit (Fallahi and Willemsen, 2002).

\section{Materials and methods}

An experiment on chemical thinning of apple blossom of the variety 'Summerred'/M9 was carried out on the experimental plantation owned by Agricultural Institute of Slovenia in Brdo pri Lukovici (lat. 46¹0'7 ", lan. 1441'5 ").

\section{Variety 'Summerred'}

'Summerred' is a significant summer variety that is sensitive to scab (Venturia inaequalis). The fruits are oblong, medium sized, dark red in colour and have nicely visible white lenticels. Ripening in the second decade of August, it is considered as one of the best summer varieties. The storage capacity is very good for the summer variety, as it is well kept in the cellar only until the end of September (Godec et al., 2011). Fertility is moderate to abundant and variable over the years. Tree growth is weak to moderately abundant. It is fairly resistant to winter frost, very susceptible to scab and very susceptible to apple mildew. The white-green ground colour changes to yellow as it matures. The fruits are juicy, medium firm, acidulous taste and pleasant aromas (Stopar and Viršček-Marn, 1998).

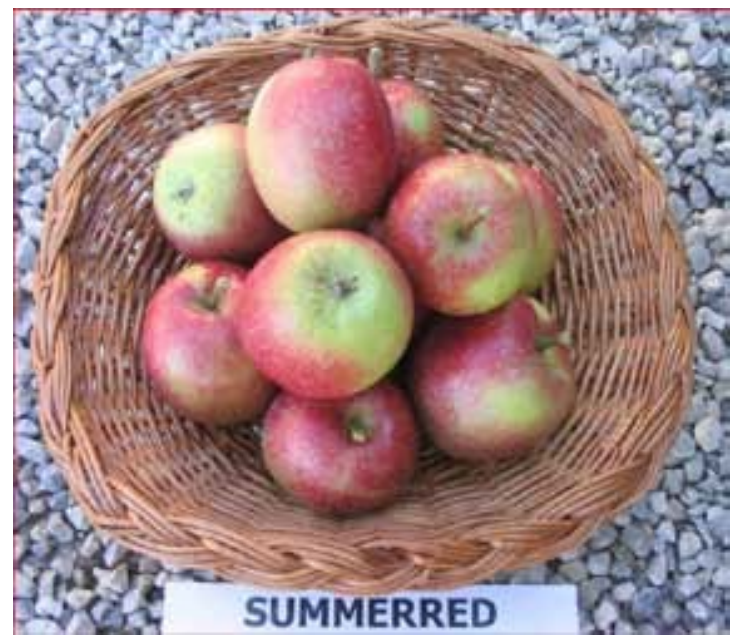

Figure 1. Variety 'Summerred'

Slika 1. Sorta 'Summerred' 
The trees were grafted on a vegetative rootstock $\mathrm{M} 9$ and planted at a distance of $3.2 \mathrm{~m} \times$ $1.8 \mathrm{~m}$; the diameter of the crown is $1 \mathrm{~m}$, the height of the tree is $2.2 \mathrm{~m}$, the form of growth is a slender spindle. Growth is suitable, but in the orchard, there is a problem with tired soil (4 generations of apple trees), the average yield amounted to $35-40 \mathrm{t} \mathrm{ha}^{-1}$, quality of fruits is satisfactory.

In a trial with 7 randomized blocks, 13 treatments were studied as follows:

1. Control) without thinning measures

2. Hand-thinned trees (June 15th, after June natural thinning)

3. $\mathrm{NaCl} 1 \%$, spraying April 30th

4. $\mathrm{NaCl} 1.5 \%$, spraying April 30th

5. $\mathrm{CH}_{3} \mathrm{COOH} 1 \%$, spraying April 30th

6. $\mathrm{CH}_{3} \mathrm{COOH} 3 \%$, spraying April 30th

7. CaSx $3 \%$, spraying April 30th

8. OGRIOL 1\%, spraying April 30th

9. OGRIOL 3\%, spraying April 30th

11. Soybean oil 3\%, spraying April 30th

12. Dextrin 5\%, spraying April 30th

13. Emulsifier $100+$ OCA 30, spraying April 30th

\section{Chemicals used for thinning}

$\mathrm{NaCl}$ - sodium chloride $(1 \% \mathrm{NaCl}, 1.5 \% \mathrm{NaCl})$

It is an ionic compound with the chemical formula $\mathrm{NaCl}$, it appears to be an odorless, colorless crystal. Salt is used in the food industry as a spice and preservative (https://pubchem. ncbi.nlm.nih.gov/compound/Sodium-chloride).

\section{Acetic acid (1\% $\left.\mathrm{CH}_{3} \mathrm{COOH}, 3 \% \mathrm{CH}_{3} \mathrm{COOH}\right)$}

It is an acetic acid with the chemical formula $\mathrm{CH}_{3} \mathrm{COOH}$ and is an important component of vinegar and has a distinctly acidic taste and pungent odour. It is an apparently colourless liquid. Its salts are called acetates. Anhydrous acetic acid is called glacial acetic acid because it forms ice crystals at temperatures below $16.7^{\circ} \mathrm{C}$. Although classified as a weak acid, concentrated acetic acid is corrosive. It is used in the food industry as a food additive with the designation E260, as an acidity regulator and as a spice (https://pubchem.ncbi.nlm.nih.gov/compound/176).

\section{CaSx - slag of sulfur lime or sulfur lime (active substance: calcium polysulfide)}

Sulfur lime is a natural chemical for the protection of fruit trees against different diseases and can be used to thin out apple blossoms in organic production. It is a drying agent and inhibits the growth of pollen tubes. Spraying into the blossom damages the blossom organs (burns). Thinning only affects flowers that have not yet been fertilized. Rainy and cold weather is very risky (Gutman-Kobal and Soršak, 2003).

\section{OGRIOL (rapeseed oil)}

100 g OGRIOL contain 92\% rapeseed oil + 4\% emulsifier $100+4 \%$ OCA emulsifier 30 (Oleyl Cetyl Alcohol Ethoxylate $30 \%$ ). It is used as a natural insecticide or as an additive to insecticides and herbicides to improve the adhesion and effectiveness of plants. It is also classified as a natural insecticide for use in integrated and ecological plant protection and has no quarantine (https://agrobaseapp.com/slovenia/pesticide/ogriol). 


\section{Sunflower oil}

Sunflower oil of neutral taste and aroma, made from sunflower seeds. It is most commonly used as a frying oil, for salad preparation and as an integral part of cosmetic preparations. Sunflower oil dominates lanolin acid in the form of triglycerides. It is a rich source of vegetable fatty acids which are important for the human body

\section{Soybeanoil}

It is an oil with neutral smell and taste for soya. It contains many unsaturated fatty acids. It is a natural source of vitamin $E$ and lecithin. In an experiment carried out on peaches in the USA, Pendergrass et al. (2000) found that the use of soya oil in an $8 \%$ solution destroys insects and, at a concentration of $8-10 \%$, shows the ability to thin out flowers and fruit.

\section{Dextrin-starch}

Dextrin (polysaccharide) is a yellowish powder produced by hydrolysis, frying or enzymatic decomposition of starch. It is soluble in water and is used as a thickening agent in food.

\section{Emulsifier $100+$ OCA 30}

Emulsifiers are substances which make it possible to produce or maintain a homogeneous mixture of two or more incompatible phases. Emulsifier 100 stands for $100 \%$ polyoxyethylene. In a mixture of oil and water, the oil is sprayed into the water in the form of fine droplets to form an emulsion. Without the emulsifier, the oil would flow upwards and the water would remain below. One of the main characteristics of emulsifiers is foaming (production of cream). They are the main component of cleaning products. They are used in the pharmaceutical and food industry (e.g. lecithin). As molecules they have a characteristic chemical structure - one part of the molecule is hydrophilic (melts in water), the other part melts in fats (https://pubchem.ncbi. nlm.nih.gov/patent/US-2014206820-A1).

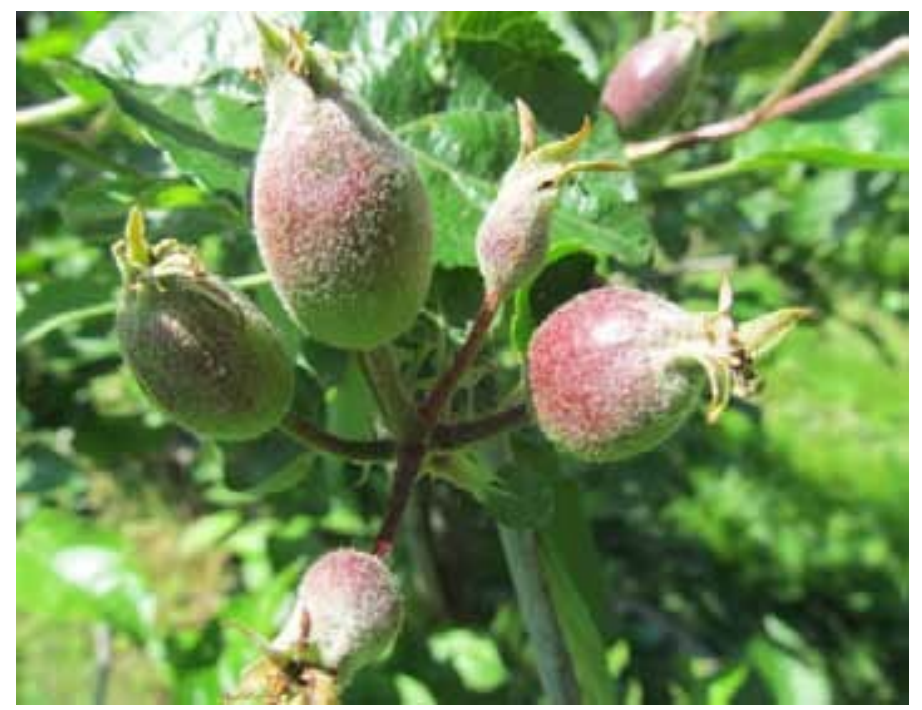

Figure 2. 'Summerred' during chemical thinning

Slika 2. 'Summerred' za vrijeme pokusa prorjeđivanja 
Table 1 shows the time of application as well as the mean values of temperature and relative humidity. Temperatures during morning spraying ranged from $9.2{ }^{\circ} \mathrm{C}$ to $19{ }^{\circ} \mathrm{C}$ and humidity from $54 \%$ to $86.7 \%$. The morning application is more effective because it is done on a wet surface. The lower temperature also influences the slower drying of the droplets.

Table 1. Time (hour), temperature $\left({ }^{\circ} \mathrm{C}\right)$ and humidity (RH \%) during experiment

Tablica 1. Vrijeme primjene prorjeđivača (sat), temperatura $\left({ }^{\circ} \mathrm{C}\right)$ i vlažnosti zraka $(\mathrm{RH}, \%)$ tijekom eksperimenta

\begin{tabular}{lccc}
\hline Treatment/Tretman & Time/Vrijeme & $\begin{array}{c}\text { Temperature } \\
\text { Temperatura }\left({ }^{\circ} \mathrm{C}\right)\end{array}$ & Humidity/Vlaga (\%) \\
\hline $\mathrm{NaCl} 1 \%$ & $7: 30$ & 11,2 & 75 \\
\hline $\mathrm{NaCl} 1,5 \%$ & $7: 40$ & 9.2 & 86.4 \\
\hline $\mathrm{CH}_{3} \mathrm{COOH} 1 \%$ & $8: 25$ & 10.8 & 83 \\
\hline $\mathrm{CH}_{3} \mathrm{COOH} 3 \%$ & $8: 40$ & 12.2 & 81 \\
\hline $\mathrm{CaS}_{\mathrm{x}}$ 3\% & $8: 00$ & 9.3 & 86.7 \\
\hline OGRIOL 1\% & $9: 05$ & 12.7 & 79.6 \\
\hline OGRIOL 3\% & $9: 20$ & 14.2 & 76 \\
\hline Sunflower oil 3\% & $9: 45$ & 16 & 72 \\
\hline Soybean oil 3\% & $10: 00$ & 17 & 64 \\
\hline Dextrin 5\% & $10: 30$ & 19 & 61 \\
\hline Emulsifier 100 + OCA 30 & $10: 45$ & 18.8 & 54 \\
\hline
\end{tabular}

\section{Evaluation of experiment}

After spraying, we started to evaluate:

(a) number of inflorescences per tree before spraying; inflorescences were counted on April 20; shortly before blooming we selected balanced trees according to the number of flower appendages for the experiment

(b) number of fruits per tree; we counted them during harvest on August 15.

(c) phytotoxicity was assessed on the tree at weekly intervals after completion of spraying. The first time was on May 5th, followed by six evaluations once a week, the last time in the twelfth week after spraying. Phytotoxicity is a common visual assessment of the effects of a whole tree, damage to leaves, shoots and flowers caused by the use of chemical agents. A scale from 1 to 10 is used:

- 1 - no phytotoxicity, 5 - moderately infested tree, 10 - destroyed tree

d) Evaluation of fruit rust at harvest (evaluation scale from 0 to 10):

- 0 - no rust, 5 - 50\% ruby, 10 - very severe rust (100\%)

(e) weight ( $\mathrm{kg}$ ) and number of fruits per tree - during the technological maturity of the fruits we estimated the total yield on each tree. On the basis of the diameter criteria, the fruits harvested on August 24 were divided into two classes: more than $65 \mathrm{~mm}$ and less than $65 \mathrm{~mm}$. Then we counted the number of thick and tiny fruits and weighed the mass of the fat and tiny fruits separately. We estimated the number of fruits per tree, the yield in fruit weight $(\mathrm{kg})$ per tree, the average fruit weight ( $\mathrm{g}$ ), the number of fruits $65 \mathrm{~mm} \mathrm{f}$ ) Estimation of reblooming (blooming the next year) - in the following years we estimated the blooming during the whole blooming period. Blooming scale from 1 (not blooming) to 10 (very rich blooming) 


\section{Statisticalanalysis}

The results obtained from various measurements were processed by IBM SPSS Statistics 23. By analysis of variance (ANOVA) we determined the effect of chemical thinning of different treatments. Duncan's test at $p<0.05$ was used for statistically significant differences between the mean of individual treatments for a given parameter.

\section{Results and discussion}

\section{Number of inflorescences per tree}

Table 2 shows the average number of inflorescences per tree for the individual treatment at the time of the trial design. The average number of inflorescences for different treatments was between 126 and 154, which means that there were no statistically significant differences between the trees at the beginning of the experiment. This means that we have come to an impartial trial from the point of view of the initial gender.

Table 2. Average number of blossom on tree

Tablica 2. Prosječan broj cvatova po stablu

\begin{tabular}{|c|c|}
\hline $\begin{array}{l}\text { Treatment/ } \\
\text { Tretman }\end{array}$ & $\begin{array}{l}\text { Average number of blossom per tree/ } \\
\text { Prosječan broj cvatova po stablu }\end{array}$ \\
\hline dextrin $5 \%$ & $126^{a}$ \\
\hline manually thinned trees & $128^{a}$ \\
\hline CaSx 3\% & $129^{a}$ \\
\hline emulsifier $100+$ OCA 30 & 130 ab \\
\hline $\mathrm{NaCl} 1,5 \%$ & $133^{b}$ \\
\hline OGRIOL 3\% & $133^{b}$ \\
\hline Control & $139^{c}$ \\
\hline CaSx 3\% & $141^{c}$ \\
\hline $\mathrm{NaCl} 1 \%$ & $142^{c}$ \\
\hline $\mathrm{CH}_{3} \mathrm{COOH} 3 \%$ & $147 d$ \\
\hline OGRIOL 3\% & $149 d$ \\
\hline Soybean oil 3\% & $150 \mathrm{~d}$ \\
\hline $\mathrm{CH}_{3} \mathrm{COOH} 3 \%$ & 154 e \\
\hline
\end{tabular}

a,b,c,d,e,f significant at $\mathrm{p}<0,05$ (Duncan)

\section{Number of fruits per tree}

Graph 1 shows the average number of fruits per tree for individual treatment. The smallest fruits were found on manually thinned trees (62) and the largest (104) on control. An insignificant effect was measured at $1 \%$ acetic acid (99 fruits per tree), 3\% CaSx, 3\% sunflower oil (92 fruits per tree) and 5\% dextrin (91 fruits). Significantly the largest effect on fruit thinning was measured in $3 \%$ oilseed rape with 63 fruits. There was a statistically significant decrease in the use of $1.5 \% \mathrm{NaCl}$ and $3 \%$ soybean oil ( 72 fruits per tree). 


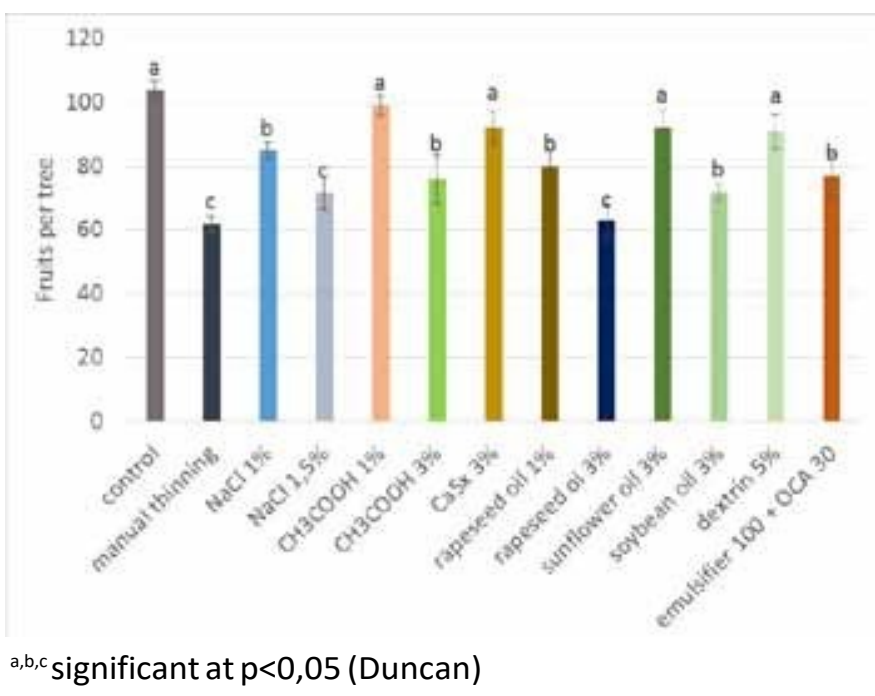

Graph 1. Average number of fruits per tree

Grafikon 1. Prosječan broj plodova po stablu

\section{Fruityield per tree}

Apples were harvested on August $15^{\text {th }}$. Graph 2 shows the average yield in fruit weight $(\mathrm{kg})$ per tree. The highest yield was measured on trees treated with $1 \%$ acetic acid (10.1 kg per tree), followed by treatment with $3 \%$ sunflower (9.9 $\mathrm{kg}$ per tree). Trees sprayed with $1.5 \% \mathrm{NaCl}$ and $3 \%$ soybean oil came closest to the results manual thinning ( $8.4 \mathrm{~kg}$ per tree). This speaks for the very successful effect of these two chemical thinners. The significantly lowest yield of $7 \mathrm{~kg}$ per tree was achieved when treated with $3 \%$ rapeseed oil, indicating a probable over-effect at this concentration.

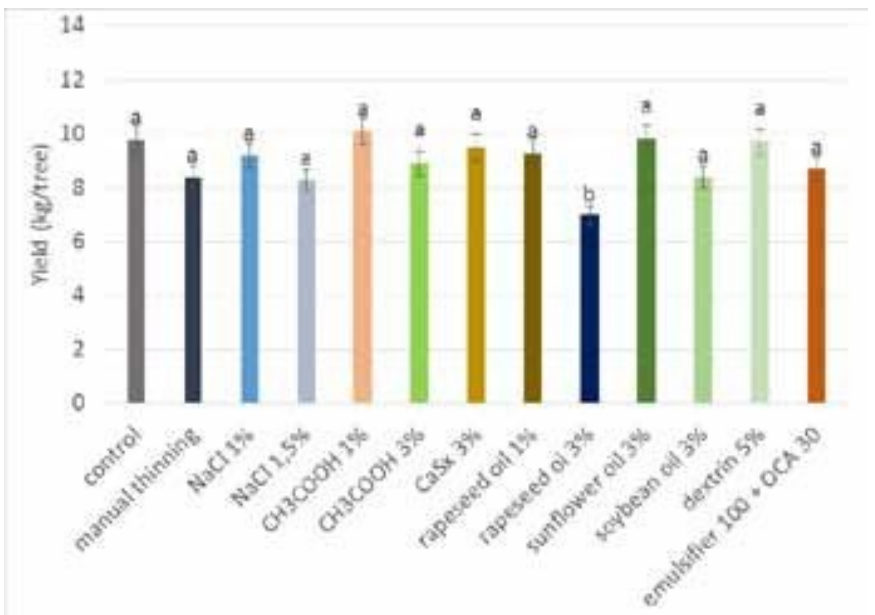

a,b,c significant at $p<0,05$ (Duncan)

Graph 2. Yield of apple fruit per tree

Grafikon 2. Prinos plodova po stablu 


\section{Rusty fruits}

Graph 3 shows the condition of the fruit skin at harvest time. The highest brown coloration was found in fruits sprayed with emulsifier $100+$ OCA 30 (2.6 points) and 3\% rape seed oil (2.3 points). Fortunately, such a degree of rust does not represent a significant market barrier for the variety "Summerred". The lowest rust content of treated fruits (1.3 points) was $1 \%$ and $3 \%$ acetic acid concentration, $3 \% \mathrm{CaSx}$ and $5 \%$ dextrin. This means that the rust content of the fruits increased only slightly compared to the control. Also Lordan et al. (2018) found that olive oil significantly influences the occurrence of rust in all types of apples. Due to the pronounced rust in yellow fruit varieties such as 'Golden Delicious', the use of oil is practically useless as it lowers the market price of apples.

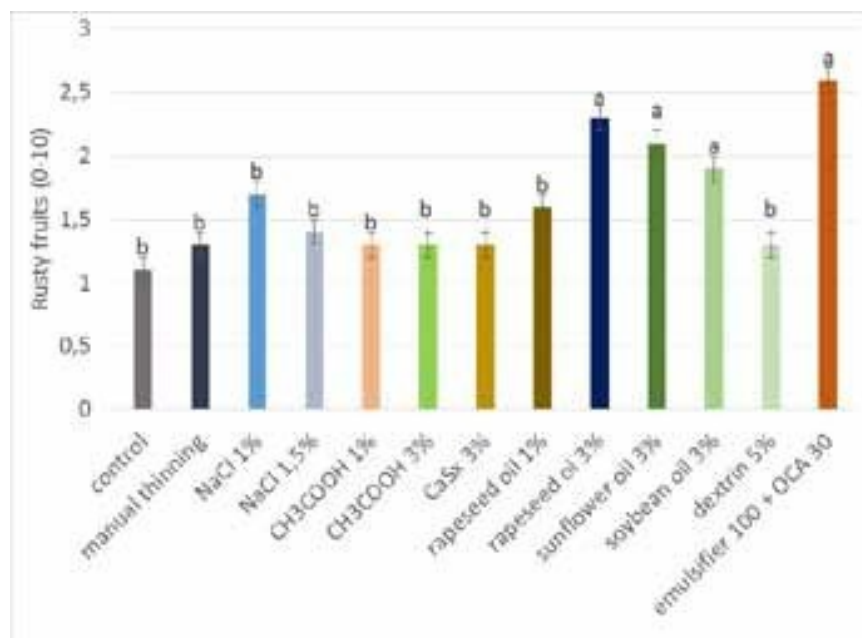

a,b,c significant at $p<0,05$ (Duncan)

Graph 3. Rusty fruits in individual treatment

Grafikon 3. Rđavost plodova u individualnom tretmanu

\section{Estimation of reblooming}

Graph 4 shows an estimate of the reblooming of the 'Summerred' trees next spring. Untreated trees did not blossom at all due (1 points) to the high alternating fertility. In general, all trees in the experiment blossom poorly and there were no significant differences between treatments. The cause of the poor reblooming could be attributed to the relative overloading of the trees with flowers and later with fruits in weak, densely planted trees of the variety 'Summerred'. All treated trees were given a score of 1.1 to 2.8 points. The weakest blooming trees were sprayed with $1 \%$ rape oil and $3 \%$ soybean oil (1.1 points) and $3 \%$ sunflower oil (1.3 points). The most abundantly blooming trees were sprayed with $3 \%$ acetic acid ( 2.8 points) and $3 \% \mathrm{CaSx}$ ( 2.7 points), followed by $1.5 \% \mathrm{NaCl}$ and $5 \%$ dextrin (2.4 points). These trees achieved the highest estimates for reblooming. A strong aphid infestation can also be blamed for the poor development of the flower buds. 


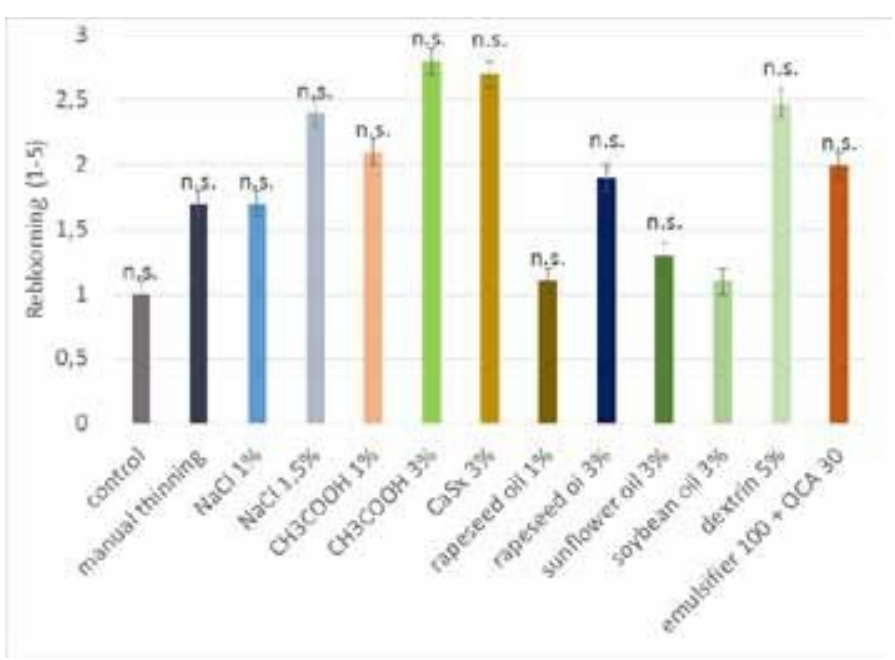

n.s. not significant at $p<0,05$ (Duncan)

Graph 4. Estimation of reblooming

Grafikon 4. Procjena povratne cvatnje

\section{Phytotoxicity}

The phytotoxicity of oils is expressed by leaf folding or limited leaf and shoot growth. Graph 5 shows that the most damaged trees were sprayed with $3 \%$ acetic acid and $1.5 \% \mathrm{NaCl}$. The maximum phytotoxicity was observed in period between one week to one month after spraying. After six weeks the effect of phytotoxicity was less pronounced.

One week after spraying the phytotoxicity at 3\% CaSx was slightly less than with $3 \%$ acetic acid and $1.5 \% \mathrm{NaCl}$, and after 6 weeks it was minimal. $3 \% \mathrm{CaSx}$ caused bleaching of the leaves and was observed more than a month later, which increased the occurrence of phytotoxicity. When 3\% CaSx was used, there was a decrease in the growth of young leaves and shoots, while the leaf margins were more often marked by the use of acetic acid and $\mathrm{NaCl}$ in both concentrations.

When using 3\% rapeseed oil, the phytotoxic effect was less pronounced compared to acetic acid, $\mathrm{NaCl}$ and $\mathrm{CaSx}$. Spraying with $3 \%$ sunflower oil and $3 \%$ soybean oil resulted in a similar phytotoxicity as using $3 \%$ rapeseed oil, while $5 \%$ dextrin had no phytotoxic effect. In the first three weeks after spraying with emulsifier $100+$ OCA 30 the phytotoxicity was similar to the application of $3 \%$ rapeseed oil, but for another 2 weeks. When using low concentrations of acetic acid, $\mathrm{NaCl}$ or rape seed on "Summerred" apple, the phytotoxicity was more difficult to detect compared to its higher concentrations. 


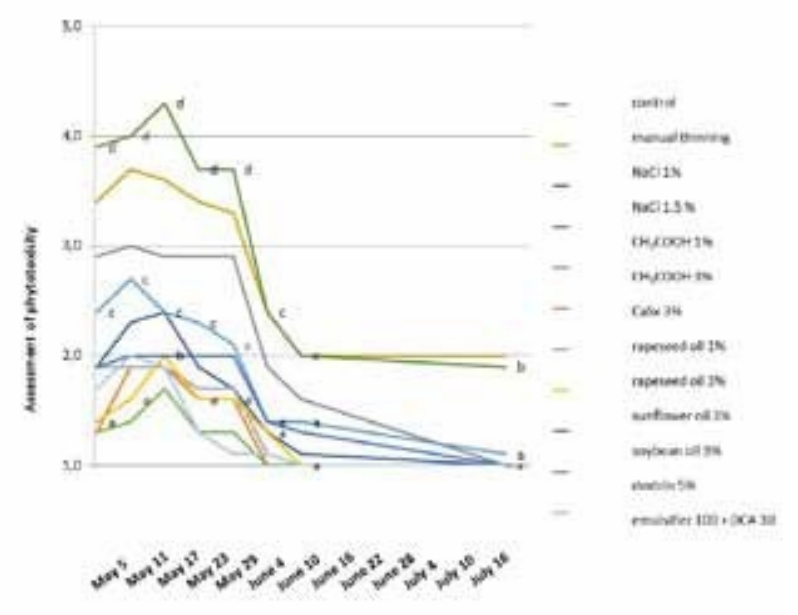

${ }^{a, b, c}$ significant at $p<0,05$ (Duncan)

Graph 5. Assessment of phytotoxicity

Grafikon 5. Ocjena fitotoksičnost

\section{Conclusion}

In a practical experiment, several chemicals for thinning the bloosom of the ecologically cultivated summer variety 'Summerred' were investigated. As there is no known literature on experimental thinning of flowers of this variety, several potentially useful chemicals were used: $1 \% \mathrm{NaCl}, 1.5 \% \mathrm{NaCl}, 1 \% \mathrm{CH}_{3} \mathrm{COOH}, 3 \% \mathrm{CH}_{3} \mathrm{COOH}, 3 \% \mathrm{CaSx}, 1 \%$ rape oil, 3\% rape oil, 3\% sunflower oil, $3 \%$ soybean oil, $5 \%$ dextrin and emulsifier $100+$ OCA 30 . They dilute different oils best, but unfortunately their side effect is fruit peel rust and was greatest when sprayed with emulsifier $100+$ OCA 30 (2, 6 points) and 3\% rapeseed oil (2.3 points). Even when sprayed with other oils, more rust was found on the fruits compared to other treatments.

The highest phytotoxicity was observed when $3 \%$ acetic acid, $1.5 \% \mathrm{NaCl}$ or $3 \% \mathrm{CaSx}$ were used. The data show that after using low concentrations of acetic acid and $\mathrm{NaCl}$ a lower phytotoxic effect was observed compared to their higher concentrations. Different oil concentrations caused a less pronounced phytotoxic effect compared to acetic acid, $\mathrm{NaCl}$ and $\mathrm{CaSx}$.

A very important result of the thinning is the number of fruits and their thickness. $1 \%$ rape oil and 3\% acetic acid did not dilute the fruits very much, but these trees had the biggest fruits and the highest average fruit weight. Both treatments resulted in a statistically significant increase in average fruit weight compared to untreated trees. $1 \% \mathrm{CH}_{3} \mathrm{COOH}, 3 \% \mathrm{CaSx}, 3 \%$ sunflower oil and 5\% dextrin had no major effect on fruit thinning and reduced the number of fruits only slightly. The biggest effect on fruit thinning was 3\% rape seed oil and at the same time the lowest average fruit yield $(\mathrm{kg})$ per tree, even less than in manually thinned trees. This indicates a probable overactivity of this agent at this concentration.

The evaluation of reblooming is also very important when dilutors are used. The weakest trees were sprayed with $1 \%$ rape oil and $3 \%$ soybean oil (1.1 points) and the most luxuriant trees with $3 \%$ acetic acid ( 2.8 points).

As the experiment was not performed on optimal 'Summered' trees before organic chemical thinning preparations can be recommended, several further experiments have to be per- 
formed to clarify the answer to all thinning questions and possible phytotoxicity. According to our findings, the chemical thinning of apple buds in organic cultivation with $3 \%$ soybean oil and $1.5 \% \mathrm{NaCl}$ could be performed relatively well.

\section{Literature}

Alrashedi, M., Singh, Z. (2014) Effi y of lime sulphur alone and in combination with olive oil on blossom thinning in organically grown 'Cripps Pink' and 'Gala' apples. Acta Hortic. 1119, 25-34.

Asteggiano, L., Giordani, L., Bevilacqua, A., Vittone, G., Pellegrino, S., Costa, G. (2015) Bloom mechanical thinning improves fruit quality and reduces production costs in peach. Acta Hortic. 1084, 389-394.

Blanke, M., Damerow, L. (2008) A novel device for precise and selective thinning in fruit crops to improve fruit quality. Acta Hortic. 824, 275-280.

Brvar M. (2015) Kemično redčenje plodičev jablane pri sorti 'Summerred' v ekološki pridelavi, Dipl. delo, Maribor, Univerza v Mariboru, Fakulteta za kmetijstvo in biosistemske vede.

Davies, P.J. (2004) Plant hormones; Biosynthesis, Signal Transduction, Action! , Revised $3^{\text {rd }}$ addition, 802 pp. Springer, Dordrecht, https://doi.org/10.1007/978-1-4020-2686-7.

Dorigoni, A., Lezzer, P., Micheli, F., Dallabetta, N., Pasqualini, J. (2010) Diradare il melo a macchina: cosa sapere per farlo bene. L'informatore agrario 22, 63-68.

Fallahi, E., Willemsen, K.M. (2002) Blossom thinning of pome and stone friut. HortScience, 37 (3): 474-477.

Godec, B. (2014) Jabolka iz osrčja Slovenije. Ljubljana, Kmetijski inštitut Slovenije: 6.

Greene, D., Costa, G. (2012) Fruit thinning in pome-and stone-fruit: state of the art. Acta Hortic. 998, 93-102.

Gutman-Kobal, Z., Soršak, A. (2003) Tehnološka navodila za pridelovanje jabolk. Ljubljana, Kmetijsko gozdarska zbornica Slovenije: 17-52.

Hampson, C., Bedford, K. (2011) Effi y of blossom thinning treatments to reduce fruit set and increase fruit size of Ambrosia and Aurora Golden Gala ${ }^{\mathrm{TM}}$ apples. Can. J. Plant Sci. 91 (6), 983-990.

Jerala, T. (2005) Uporaba ocetne kisline in kalcijevega polisulfi za kemično redčenje plodičev jablane v ekološki pridelavi. Dipl. delo., Ljubljana. 41: 11.

Kon, T.M., Schupp, J.R., Winzeler, H.E., Marini, R.P. (2013) Infl e of mechanical string thinning treatments on vegetative and reproductive tissues, fruit set, yield, and fruit quality of 'Gala' apple. HortScience, 48 (1), 40-46.

Lordan, J., Alins, G., Àvila, G., Torres, E., Carbó, J., Bonany, J., Alegre, S. (2018) Screening of eco-friendly thinning agents and adjusting mechanical thinning on 'Gala', 'Golden Delicious' and'Fuji' apple trees. Scientia Horticulturae, 239, 141-155.

McClure, K.A., Cline, J.A. (2015) Mechanical blossom thinning of apples and infl

e on yield, fruit quality and spur leaf area. Can. J. Plant Sci., 95 (5), 887-896.

Mika, A., Buler, Z., Treder, W. (2016) Mechanical pruning of apple trees as an alternative to manual pruning. Acta Scientiarum Polonorum-Hortorum Cultus, 15 (1), 113-121.

Ngugi, H.K., Schupp, J.R. (2009) Evaluation of the risk of spreadingfi e blight in apple orchards with a mechanical string blossom thinner. HortScience, 44 (3), 862-865.

Pendergrass, R., Roberts, K.R., Deyton, E.D., Sams, E.C. (2000) Economics of using soybean oil to reduce peach freeze damage and thin fruit. HortScience, 10: 211-217.

Pfeiffer, B., Rueß, F. (2002) Screening of agents for thinning blossoms of apple trees. 10th International Conference on Cultivation Technique and Phytopathological Problems in Organic Fruit-Growing and Viticulture. Proceedings to the Conference from 4th to 7th Feb. 2002 at Weinsberg, Germany.

Reighard, G.L., Henderson, W.G. (2012) Mechanical blossom thinning in South Carolina peach orchards. Acta Hortic, 965, 117-121.

Schupp, J.R., Kon, T.M. (2014) Mechanical blossom thinning of 'GoldRush'/M.9 apple trees with two string types and two timings. J. Am. Pomol. Soc., 68 (1), 24-31.

Seehuber, C., Damerow, L., Kunz, A., Blanke, M. (2010) Mechanical thinning reduces June drop and improves fruit quality i.e. fruit size of cv. 'Conference' and 'A. Lucas' pear. Erwerbs-Obstbau, 52 (2), 45-53.

Sinatsch, S., Pfeiffer, B., Toups, I., Zimmer, J., Benduhn, B. (2010) Comparison of different thinning measures for organic grown apples (cultivar 'Pinova'). In: Ecofruit. 14th International Conference on Organic Fruit-Growing. Proceedings for the Conference, Hohenheim, Germany. 22-24 February.

Steyn, W., Theron, K., De Villiers, M. (2014) The effect of mechanical bloom thinning with the Darwin 300 TM, on the hand thinning time, yield, and fruit quality in 'Zephyr' nectarine. Acta Hortic, 1130, 631-638.

Stopar, M., Viršček-Marn, M. (1998) Sorte jabolk. Ljubljana, Kmečki glas: 170-199.

Wertheim, S.J. (2000). Developments in the chemical thinning of apple and pear. Plant growth regulation, 31: 85-100.

On-line

$\mathrm{NaCl}, 2020$. URL: https://pubchem.ncbi.nlm.nih.gov/compound/Sodium-chloride (26. 11. 2020)

Acetic acid, 2020. URL: https://pubchem.ncbi.nlm.nih.gov/compound/176 (26.11. 2020)

Emulgator 100, URL: https://pubchem.ncbi.nlm.nih.gov/patent/US-2014206820-A1 (26.11. 2020)

OGRIOL, URL: https://agrobaseapp.com/slovenia/pesticide/ogriol (26. 11. 2020)

Prispjelo/Received: 24.7.2020.

Prihvaćeno/Accepted: 30.11.2020. 


\section{Kemijsko prorjeđivanje cvjetova jabuke u ekološkoj proizvodnji}

\section{Sažetak}

Na eksperimentalnoj plantaži (Brdo pri Lukovici) proveden je pokus kemijskog prorjeđivanja cvjetova jabuke sorte 'Summerred' cijepljene na podlozi M9. Cilj eksperimenta bio je ispitati učinke različitih sredstava koji se koriste u jabukama u ekološkoj proizvodnji. U pokusu sa 7 randomiziranih blokova i 13 tretmana proučavan je utjecaj: 1. neprorijeđeno, 2. ručno rijeđeno u lipnju, 3. $1 \% \mathrm{NaCl}, 4.1,5 \% \mathrm{NaCl}, 5.1 \% \mathrm{CH}_{3} \mathrm{COOH}, 6.3 \%$ $\mathrm{CH}_{3} \mathrm{COOH}, 7.3 \%$ vapneni sumpor $\mathrm{CaSx}, 8.1 \%$ ulje uljane repice, 9. 3\% ulje uljane repice, 10. 3\% suncokretovo ulje, 11. 3\% sojino ulje, 12.5\% dekstrin, 13. emulgator $100+$ OCA 30. Kemijski prorjeđivači primijenjeni su u fenološkom stadiju u vrhuncu cvjetanja. Najbolje prorjeđivanje plodova, slično onima s rukom, zabilježeno je pri nanošenju 3\% ulja uljane repice. Prilikom ovog tretmana uočena je razmjerno jaka rđavost kože ploda. Statistički značajna manji broj plodova također se pojavilo kada je raspršeno 1,5\% NaCl i 3\% sojinog ulja, ali s manje izraženom rđavošću jabuka.

Ključne riječi: jabuka, kemijsko prorjeđivanje, ekološka proizvodnja

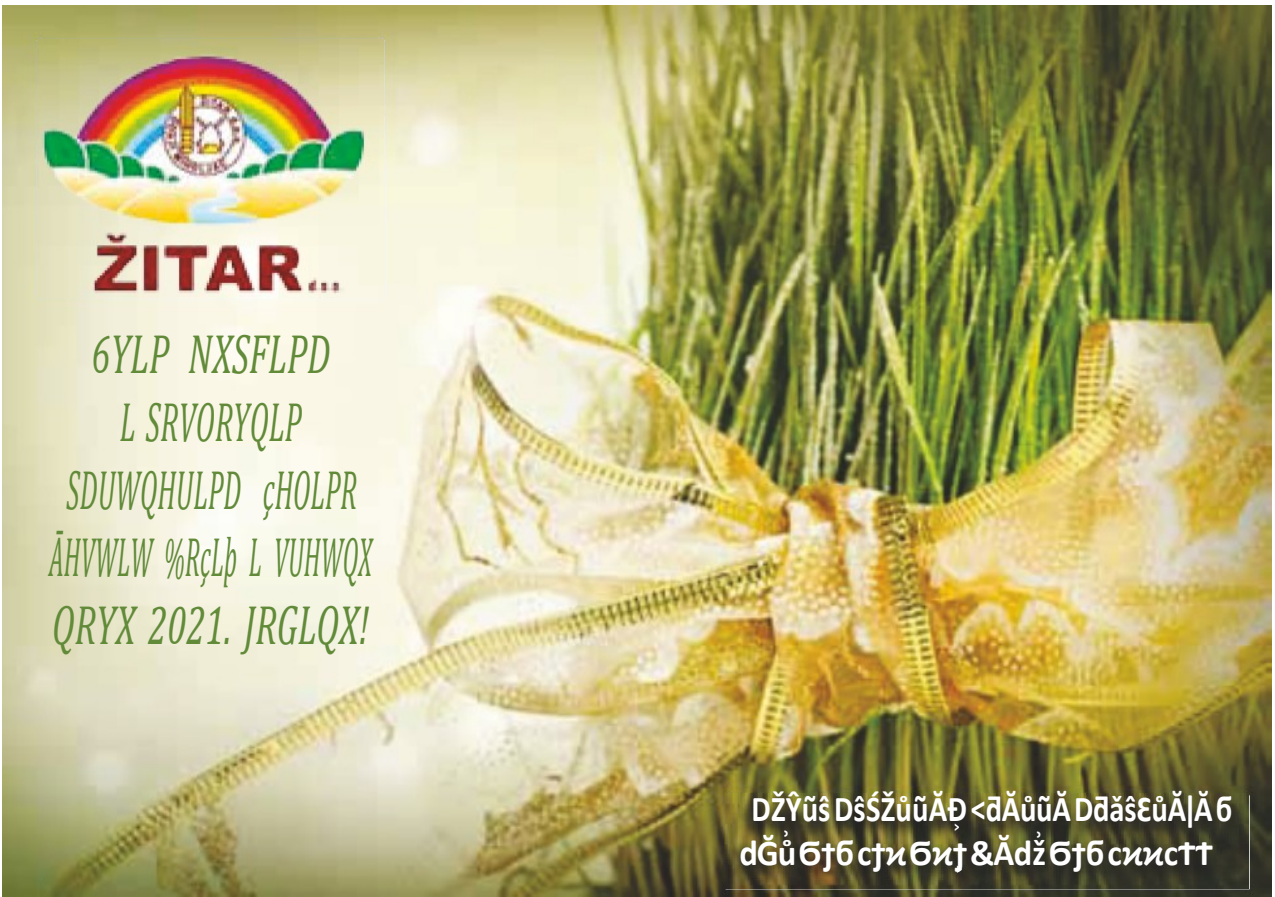

